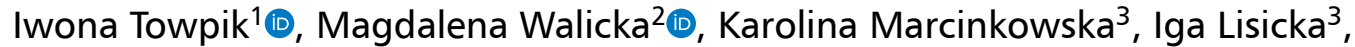
Marta Raczyńska ${ }^{3}$, Waldemar Wierzba ${ }^{4},{ }^{5}$, Krzysztof Strojek ${ }^{6}$, Przemysław Ryś 7 , Małgorzata Wajda-Cuszlag ${ }^{8}$ (D) Edward Franek ${ }^{2,9}$ (D)

${ }^{1}$ Department of Internal Diseases, Collegium Medicum, University of Zielona Góra and Department of Internal Diseases University Hospital of Karol Marcinkowski, Zielona Góra

2Department of Internal Diseases, Endocrinology and Diabetology Central, Clinical Hospital of the Ministry of the Interior and Administration, Warsaw

${ }^{3}$ Department of Analyses and Strategies, Ministry of Health, Warsaw

${ }^{4}$ University of Humanities and Economics, Lodz

${ }^{5} \mathrm{Clinical}$ Hospital of the Ministry of the Interior and Administration, Warsaw

${ }^{6}$ Department of Internal Diseases Diabetology and Cardiometabolic Diseases Faculty of Medical Sciences Zabrze; Medical University of Silesia, Katowice ${ }^{7}$ HTA Consulting, Kraków

${ }^{8}$ Department of Endocrinology and Diabetology, The Children's Memorial Health Institute, Warsaw

${ }^{9}$ Department of Human Epigenetics, Mossakowski Medical Research Centre, Warsaw

\title{
Epidemiology of diabetes in Poland in 2014-2017
}

\section{ABSTRACT}

Background. The number of people with diabetes increases every year, both in Poland and worldwide. In Poland, the exact number is not known, and the latest data comes from 2014. The aim of the study was to assess basic epidemiological indicators regarding diabetes in Poland in 2014-2017.

Material and methods. Division into types of diabetes and other analyzes was carried out on the basis of data prepared by a team of experts and employees of the Department of Analysis and Strategy of the Ministry of Health. The NHF databases were used, concerning realized medical interventions and refunded prescriptions. Results. The number of people with diabetes in Poland in 2014 was 2.113 million (1.167 million women and 0.946 million men). This number increased in subsequent years and in 2017 amounted to 2.533 million (1.408 million women and 1.124 million men), which constituted $6.58 \%$ of the population. Using the adopted methodology, the number of patients in whom the type of diabetes could not be determined was large and ranged from $39.57 \%$ to $32.75 \%$ in individual years.

Address for correspondence:

prof. dr hab. n. med. Edward Franek

Klinika Chorób Wewnętrznych, Endokrynologii i Diabetologii CSK MSWiA

Wołoska 137, 02-507 Warszawa

Phone: 22 5081405, fax 225081400

e-mail: edward.franek@cskmswia.pl

Translation: dr n. med. Piotr Jędrusik

Clinical Diabetology 2020, 9; 5: 279-285

DOI: $10.5603 /$ DK.2020.0033

Received: 18.05.2020

Accepted: 12.06 .2020
Conclusions. Diabetes prevalence in Poland is increasing. The adopted methodological assumptions regarding the division criteria for type 2 and type 1 diabetes do not allow an accurate determination of the epidemiology of diabetes by type (incidence rate and morbidity), but they allow to determine "specific" subpopulations of patients with a given type of disease. (Clin Diabetol 2020; 9; 5: 279-285)

Key words: diabetes, morbidity, Poland, National Health Fund

\section{Introduction}

Diabetes is a group of metabolic disorders characterized by chronic hyperglycaemia which leads to damage, dysfunction, and failure of various organs [1]. The European Parliament declaration of Apr 16, 2006, and the United Nations resolution of Dec 20, 2006 both declared diabetes the first non-infectious epidemic disease that poses a worldwide public health threat [2].

In the 2016 World Health Organization (WHO) report on diabetes, the number of patients with this disease worldwide in 2014 was estimated at 422 million [3]. As the number of patients with diabetes in 1980 was 108 million, it can be concluded that the global prevalence of diabetes increased nearly 4-fold over 34 years. Experts of the International Diabetes Federation (IDF) predict that the number of patients with diabetes worldwide, estimated at 463 million in 2019 , will increase to 700 million in 2045, translating to a $51 \%$ increase over the next 25 years $[4,5]$. It is thus 
necessary to improve organization of care for diabetic patients, the directions of which were set for the first time at the international level under the auspices of WHO and IDF in the 1989 St. Vincent Declaration [6].

Appropriate planning of healthcare services must be based on reliable epidemiological data which are also of significant prognostic importance. However, the number of patients with diabetes in Poland has not been precisely estimated, and there is no national Polish population registry of diabetic patients. The data on the scope of diabetes problem in Poland come from studies performed in various age groups, specific regions, or focusing on other health problems that also provided information on diabetes. Most commonly cited studies such as the regional Pol-MONICA study and multicentre national WOBASZ II and NATPOL 2011 surveys evaluated cardiovascular disease risk factors [7-9]. The POLSENIOR study evaluated the health status of the population above 65 years of age [10]. Data provided by WHO and IDF are based on information collected from specific countries, and if such data are unavailable, these are only estimates based on data from countries at a similar level of development and with similar demographic characteristics of the population [5]. This necessitates the search for other reliable sources of information that would allow defining the morbidity due to diabetes in Poland. In the recent years, such opportunities have been provided by the databases of contracted health services and medication reimbursement run by the National Health Fund (Narodowy Fundusz Zdrowia, NFZ) which is the only public healthcare payer in Poland. Such an analysis was performed for years 2010-2014 [11]. Another analysis was performed for the year 2013 by the expert panel of the Polish Academy of Sciences, convened to evaluate the epidemiology of diabetes in Poland and the quality of public reporting in this area. Data sources included NFZ databases, results of the ReceptoMetr and NATPOL 2011 studies, and regional registries of children with diabetes [12].

Since 2014, with the introduction of the Maps of Health Needs in Poland, experts and employees of the Department of Analyses and Strategy of the Polish Ministry of Health perform analyses for the purpose of forecasting and planning healthcare related to specific health problems [13]. As the most recent analyses on the epidemiology of diabetes were performed in 2014 , the aim of the present study was to evaluate basic epidemiological indices of diabetes in Poland in 2014-2017 based on the analyses performed by the experts and employees of the Department of Analyses and Strategy of the Polish Ministry of Health using the NFZ database.

\section{Methods}

The present study was a part of the project entitled: Maps of Health Needs: Database of System and Implementation Analyses (Polish title: Mapy potrzeb zdrowotnych: Baza Analiz Systemowych i Wdrożeniowych). The project was supported by the European Union (European Social Fund, Operational Programme Knowledge Education Development) and undertaken by the Department of Analyses and Strategy at the Polish Ministry of Health (Departament Analiz i Strategii Ministerstwa Zdrowia w Polsce; http://www. mpz.mz.gov.pl).

The system of healthcare in Poland is based on an insurance model, providing the citizens with an equal access to health care services financed from public funds. The institutional healthcare payer is NFZ. It provides funds for healthcare services and reimbursement of medications, nutritional products and medical products from the collected obligatory health insurance premiums.

Healthcare providers that signed an agreement with NFZ regarding the provision of outpatient and inpatient healthcare services are obliged to run an electronical registry of these services. Data collected in these healthcare service registries include patient identifying data and the International Statistical Classification of Diseases and Related Health Problems (ICD-10) disease codes for a given service. These data are then transferred to NFZ.

Pharmacies collect data on filled prescriptions and transfer these data to NFZ. The scope of data on the turnover of medications, special nutritional products, and medical products subject to reimbursement includes the patient identifying number, and the code number (European Article Numbering, EAN) of a medication, special nutritional product, or medical product.

\section{Sources of data}

The analyses for the years 2014-2017 were performed using the following NFZ databases:

- healthcare service claim database;

- filled and reimbursed prescription database.

\section{Preparation of the baseline dataset}

The baseline dataset of persons with diabetes was defined in the following way:

- patients with the following ICD-10 codes for diabetes reported to NFZ as the primary or concomitant diagnosis were included: E10 insulin-dependent diabetes mellitus, E11 non-insulin-dependent diabetes mellitus, E12 - malnutrition-related diabetes mellitus, E13 other specified diabetes mellitus, E14 - unspeci- 
Table 1. Classification of diabetes based on healthcare service claims

\begin{tabular}{lcc}
\hline & Children (below 18 years of age) & Adults \\
\hline Type 1 & Only E10; E10 and E14 together & Only E10 \\
Type 2 & Only E11; E11 and E14 together & Only E11 \\
Undetermined & Cannot be clearly determined based on ICD-10 codes & Cannot be clearly determined based on ICD-10 codes \\
\hline
\end{tabular}

Table 2. Classification of diabetes based on the filled prescription database

\begin{tabular}{ll}
\hline Type 1 & Patient fills prescriptions for insulin or glucagon and glucose meter test strips, but not for oral medications \\
Type 2 & Patient fills prescriptions for oral medications and glucose meter test strips, but not for insulin \\
Prediabetes & Patient fills prescriptions for oral medications but not glucose meter test strips (persons with prediabetes are \\
& not entitled for reimbursement of glucose meter test strips) \\
Undetermined & None of the above conditions is met but the patient filled prescriptions for any antidiabetic medications
\end{tabular}

fied diabetes mellitus [11]. For clarity, three-digit ICD-10 codes were used, while in fact full codes (up to five digits) were taken into account;

- it was assumed that patients with diabetes should have it reported at least once as the primary diagnosis during their medical care, and patients who did not fulfil this criterion were excluded:

- patients with a reported code for cystic fibrosis were removed from the dataset;

- gestational diabetes and diabetes during pregnancy were not included due to their nature and the fact that they are covered by the 024 code together with various types of pre-pregnancy diabetes;

- finally, it was checked what antidiabetic medications and medical products (glucose meter test strips) were prescribed to patients in the dataset defined as above. Patients who filled prescriptions for oral drugs but not for glucose meter test strips were removed from the dataset as these persons might have had prediabetes (as reimbursement for glucose meter test strips does not include persons with prediabetes).

\section{The algorithm for dividing the baseline dataset into specific diabetes types}

Due to the fact that based on the ICD-10 codes reflecting diabetes management, the diabetes type according to the WHO etiological classification cannot be determined, the algorithm for dividing the baseline dataset into specific diabetes types, based on the assumption that major diabetes types are related to age. The diabetes types were defined within yearly data volumes, separately based on healthcare service claims and medications. These results were then integrated and the diabetes type was finally assigned to a given patient in a given year. The classification based on healthcare service claims is shown in Table 1.

If a patient was assigned both $\mathrm{E} 10$ and $\mathrm{E} 11$ codes, the diabetes type was determined based on the majority rule at $90 \%$ of all diagnoses reported for a given patient in a given year.

For medications, there was no need to make specific assumptions based on the patient's age, as medications define the type of diabetes. The classification based on medications is shown in Table 2 .

After the diabetes type was defined separately based on healthcare service claims and medications, these two categorizations were compared to each other. In some cases, the type defined based on the healthcare service claim database was different from the one assigned based on the medications. In these situations, diabetes type was defined based on the medications purchased by the patient. If despite the above assumptions the patient still could not be clearly assigned a diabetes type, he was categorized as undetermined diabetes type.

The age distribution of patients with diabetes type 1 and type 2 was also analysed. The peak incidence of diabetes type 1 is in the juvenile period and thus it was assumed that patients diagnosed with diabetes type 1 after the age of 40 were not appropriately categorized and were excluded from the group of patients with diabetes type 1 .

\section{Results}

The number of subjects with diabetes in Poland in 2014 was 2.113 million (1.167 million women and 0.946 million men). This number increased in the subsequent years, reaching 2.533 million in 2017 (1.408 million women and 1.124 million men). Figure 1 shows 
Table 3. Prevalence and incidence of diabetes in Poland in 2014-2017

\begin{tabular}{ccccc}
\hline Year & $\begin{array}{c}\text { Population of Poland in } \\
\text { millions according to GUS }\end{array}$ & $\begin{array}{c}\text { Number of patients } \\
\text { in millions }\end{array}$ & $\begin{array}{c}\text { Proportion } \\
\text { of patients }\end{array}$ & $\begin{array}{c}\text { New cases } \\
\text { in thousands }\end{array}$ \\
\hline 2014 & 38.48 & 2.113 & $5.48 \%$ & $5.88 \%$ \\
2015 & 38.44 & 2.261 & $6.25 \%$ & 218.32 \\
2016 & 38.43 & 2.404 & $6.58 \%$ & 217 \\
2017 & 38.43 & 2.533 & 24.05 \\
\hline
\end{tabular}

GUS - Central Statistical Office of Poland (Główny Urząd Statystyczny)

Table 4. Number of patients with diabetes (overall and specific types) in 2014-2017

\begin{tabular}{lcccc}
\hline & 2014 & 2015 & 2016 & 2017 \\
\hline Number of patients with diabetes & $2,113,099$ & $2,261,885$ & $2,404,426$ & $157,188(6.21 \%)$ \\
Type 1 & $174,547(8.26 \%)$ & $166,574(7.36 \%)$ & $161,314(6.71 \%)$ \\
Type 2 & $1,102,320(52.17 \%)$ & $1,255,190(55.49 \%)$ & $1,406,684(58.5 \%)$ & $1,546,156(61.04 \%)$ \\
Undetermined type & $836,232(39.57 \%)$ & $840,121(37.14 \%)$ & $836,428(34.79 \%)$ & $829,547(32.75 \%)$ \\
\hline
\end{tabular}

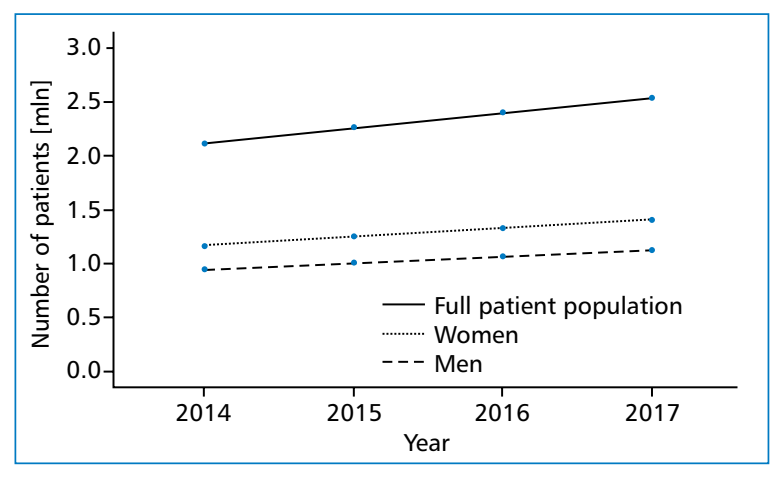

Figure 1. Number of persons with diabetes in Poland in 2014-2017

the number of subjects with diabetes in subsequent years, overall and in relation to gender, and the data on prevalence and incidence are shown in Table 3.

The proportion of patients with diabetes type 1 and 2 in the overall number of subjects with diabetes in 2014-2017 is shown in Table 4. Table 5 shows the mean patient age at the time of the diagnosis of diabetes in subsequent years.

The distribution of age in patients with diabetes type 1 at the time of the diagnosis of diabetes in subsequent years is shown in Figure 2. The distribution of age in patients with diabetes type 2 at the time of the diagnosis of diabetes in subsequent years is shown in Figure 3.

\section{Discussion}

In our analysis, we showed that the number of patients with diabetes in Poland increased from 2.113
Table 5. Mean patient age at the time of the diagnosis of diabetes in 2014-2017

\begin{tabular}{ccc}
\hline Year & $\begin{array}{c}\text { Mean age at the time } \\
\text { of diagnosis } \\
\text { - diabetes type } 1\end{array}$ & $\begin{array}{c}\text { Mean age at the time } \\
\text { of diagnosis } \\
\text { - diabetes type 2 }\end{array}$ \\
\hline 2014 & 20 & 64 \\
2015 & 20 & 64 \\
2016 & 22 & 63 \\
2017 & 21 & 63 \\
\hline
\end{tabular}

million in 2014 to 2.533 million in 2017 . The increasing prevalence of diabetes, as already noted in the introduction, has been observed worldwide and was also shown in our previous study covering the 2010-2014 period [11]. The design of the present study, however, was different. In the previous, study, based on the number of filled prescription, the number of patients with diabetes in 2014 was 2.34 million, somewhat higher compared to the present estimates. This difference is likely due to the fact that in the present study, we attempted to exclude patients with prediabetes (who did not fill prescriptions for glucose meter test strips).

In contrast, Topór-Mądry et al. [12] estimated the number of patients with diabetes (both diagnosed and undiagnosed) in Poland at 2.68 million in 2013. It should be noted, however, that our studies did not include undiagnosed diabetes. The number of patients with diabetes in Poland as reported in the IDF Diabetes Atlas 2019 is 2.34 million, but these estimates are for 


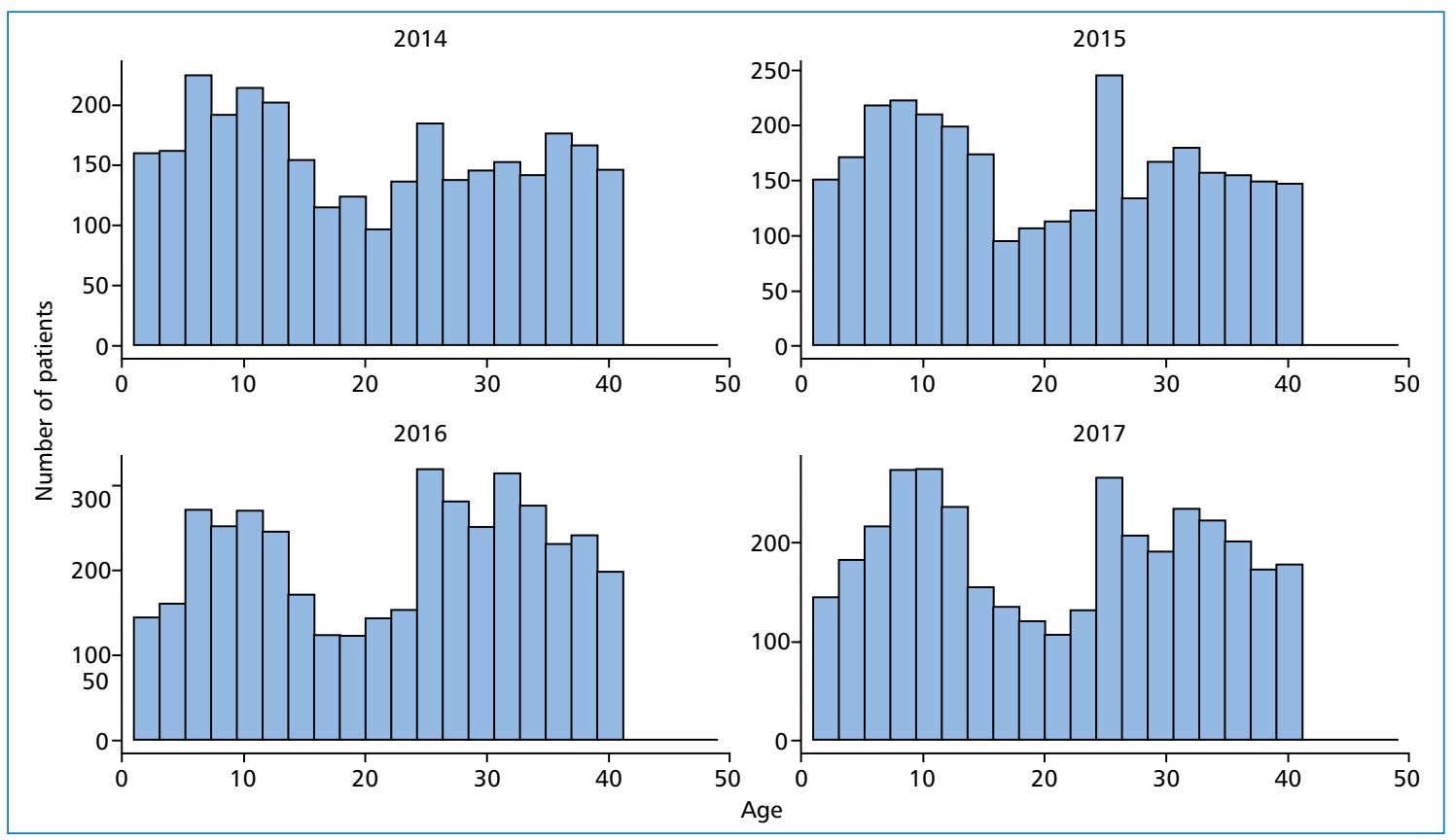

Figure 2. Distribution of age in patients with diabetes type 1 at the time of the diagnosis of diabetes in 2014-2017

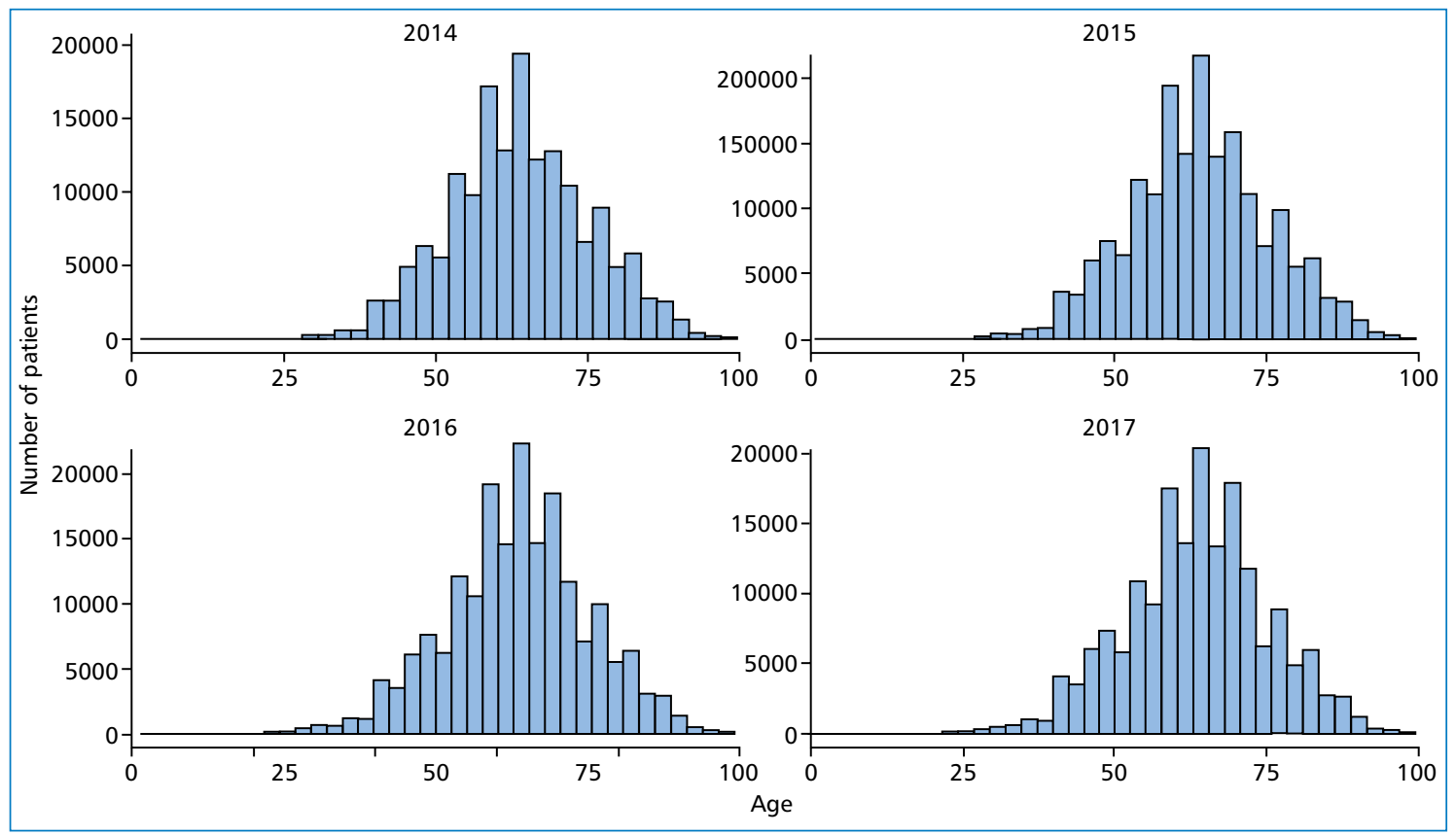

Figure 3. Distribution of age in patients with diabetes type 2 at the time of the diagnosis of diabetes in 2014-2017

the population aged $20-79$ years, and the $95 \%$ confidence interval is very wide (1.70-6.31 million).

As indicated by the above, the studies on the epidemiology of diabetes in Poland are not entirely comparable as they were performed in various regions, were targeted on patients from various age groups, focused on various types and aspects of diabetes, and differed in methodology. The same applies to comparisons with studies in other countries or regions. With these caveats in mind, it can be concluded that based on our data, the prevalence of diabetes in Poland in somewhat lower compared to the United States (where, in 2013-2016, persons with diagnosed diabetes accounted for $10.2 \%$ of the population above 18 
years of age) [14], and somewhat lower compared to Europe (where the mean prevalence of diabetes among subjects aged 20-79 years in 2019 was $8.9 \%$ ) [4]. In addition, these differences appeared despite the fact that our analysis included the whole Polish population, while the above cited reports were based on selected specific age groups.

The increasing prevalence of diabetes results, at least in part, from an increase in the number of obese subjects related to the "western" lifestyle (lack of exercise, inappropriate diet). As shown in Table 3, however, the dynamics of the increase in diabetes prevalence differed from the dynamics of diabetes incidence. The increase in diabetes prevalence was quite marked despite a relatively stable incidence. Such a trend was noted in at least some other studies. In a recently published systematic review of population studies on the incidence of diabetes overall or diabetes type 2 worldwide, it was found that the incidence of diabetes was stable in $30 \%$ of the studied populations, and showed a downward trend in $36 \%$ of the studied populations [15]. This increase in the prevalence despite a stable incidence may be due to increasing life expectancy and improving diabetes care [4] which leads to an increased survival among diabetic patients.

Diabetes type 2 accounts for about $90 \%$ of all diabetes cases $[16,17]$. In our study, however, the proportion of patients with diabetes type 2 was markedly lower, which is most likely due to the fact that our assumptions regarding the categorization into diabetes type 2 and type 1 were specific but not sensitive for diabetes type 2 . In other words, many patients could not be assigned a particular diabetes type based on the chosen criteria but the likelihood that a patient was assigned a wrong diabetes type was relatively low.

Table 4 shows a decreasing number of patients with diabetes type 1 in subsequent years. Taking into account the observed increase in the incidence of diabetes among children aged 0-14 years in most European countries in 1989-2013 (the mean annual increase in incidence was $3.4 \%$, including $6.6 \%$ in Katowice in Poland) [18], it seems that the overall number of patients with this type of diabetes might be expected to increase. It should be noted, however, that out study dealt with the general Polish population and not specific age groups.

Diabetes type 1 manifests mostly in children but may occur in all age groups (in the United Kingdom, diabetes type 1 accounts for $4 \%$ of diabetes cases diagnosed above 30 years of age) [19]. The mean age at the time of the diagnosis of diabetes type 1 in our study was 20 to 22 years in various calendar years. Distribution of age at the time of diagnosis shows two incidence peaks, one at childhood and the other one about 25-30 years of age. Studies show that every year, more cases of diabetes type 1 occur in adults than in adolescents [20]. A study performed in the United States showed an increase in the incidence of diabetes type 1 at 10-14 years of age, followed by a decrease in the incidence and later a rising trend since the age of 40 . Similarly, an increase in the incidence at 10-14 years of age followed by a reduction and then gradual increase in the incidence was observed in a study based on the population registry in Turin, Italy [21]. In studies performed in Sweden, the first increase in the incidence was observed at 0-9 years and the other one at $50-80$ years [22]. These results differ somewhat from our findings but it should be noted that one methodological assumption of our study was to exclude diabetes type 1 diagnoses made after 40 years of age.

A limitation of our study was its retrospective nature. In addition, these results only refer to the diagnosed diabetes, and it should be remembered that diabetes remains undiagnosed in about $30 \%$ of patients. In addition, available data did not allow clear determination of the diabetes type in some patients. A valuable information that would help identify patients with diabetes type 1 would be to know which patients in the baseline dataset were treated using an insulin pump. However, we did not have an access to such information at the time when the study algorithm was developed.

\section{Conclusions}

The prevalence of diabetes in Poland is increasing. In 2017, the prevalence of diabetes in the Polish population was $6.58 \%$. The adopted methodological assumptions regarding the criteria for distinguishing between diabetes type 2 and type 1 do not allow an accurate determination of the epidemiology of diabetes by type (incidence and prevalence) but they allow determining "specific" subpopulations of patients with a given type of disease. Our data will allow an analysis of the rates of complications and deaths in such groups.

\section{Conflict of interest}

The authors report no conflicts of interest.

\section{REFERENCES}

1. World Health Organization (1999). Definition, diagnosis and classification of diabetes mellitus and its complications: report of a WHO consultation. Part 1, Diagnosis and classification of diabetes mellitus. World Health Organization.

2. Zawada-Targoni S. Ogłoszenie Rezolucji Zgromadzenia Ogólnego Organizacji Narodów Zjednoczonych w sprawie intensyfikacji 
walki z cukrzycą - zwycięstwo dla dobra chorych. Med Metabol. 2007; 2: 8-9.

3. World Health Organization (2016). Global report on diabetes. World Health Organization.

4. IDF Diabetes Atlas 9th Edition 2019. http://www.idf.org/diabetesatlas dostęp 30.04.2020.

5. Saeedi P, Petersohn I, Salpea P, et al. IDF Diabetes Atlas Committee. Global and regional diabetes prevalence estimates for 2019 and projections for 2030 and 2045: Results from the International Diabetes Federation Diabetes Atlas, 9 edition. Diabetes Res Clin Pract. 2019; 157: 107843, doi: 10.1016/j.diabres.2019.107843, indexed in Pubmed: 31518657.

6. Diabetes Care and Research in Europe: The Saint Vincent DecIaration. Diabetic Med. 1990; 7(4): 360, doi: 10.1111/j.14645491.1990.tb01405.x.

7. Rywik S, Broda G, Piotrowski W, et al. Epidemiologia chorób układu krążenia. Program Pol - MONICA Warszawa. Kardiol Pol. 1996; 44(Suppl. 2): 7-35.

8. Polakowska M, Piotrowski W. Incidence of diabetes in the Polish population: results of the Multicenter Polish Population Health Status Study - WOBASZ. Pol Arch Med Wewn. 2011; 121(5): 156-163, indexed in Pubmed: 21610663.

9. Rutkowski M, Bandosz P, Czupryniak L, et al. Prevalence of diabetes and impaired fasting glucose in Poland - the NATPOL 2011 Study. Diabet Med. 2014; 31(12): 1568-1571, doi: 10.1111/ dme.12542, indexed in Pubmed: 24975751.

10. Januszkiewicz-Caulier J, Mossakowska M, Zdrojeski T, et al. Cukrzyca i jej powikłania w podeszłym wieku. In: Więcek A, Błędowski $P$ (ed.). Aspekty medyczne, psychologiczne, socjologiczne i ekonomiczne starzenia się ludzi w Polsce. Termedia Wydawnictwo Medyczne, Poznań. 2012: 169-179.

11. Walicka M, Chlebus M, Brzozowska M, et al. Prevalence of diabetes in Poland in the years 2010-2014. Clin Diabetol. 2016; 4(6): 232-237, doi: 10.5603/dk.2015.0031.

12. Topor-Madry R, Wojtyniak B, Strojek K, et al. Prevalence of diabetes in Poland: a combined analysis of national databases. Diabet Med. 2019; 36(10): 1209-1216, doi: 10.1111/dme.13949, indexed in Pubmed: 30889281.

13. Ustawa z dnia 21 marca 2014 r. o zmianie ustawy o świadczeniach opieki zdrowotnej finansowanych ze środków publicznych oraz niektórych innych ustaw. Dz.U. 2014 poz. 619, Rozporządzenie Ministra Zdrowia z dnia 26 marca 2015 r. w sprawie zakresu treści map potrzeb zdrowotnych. Dz.U. 2015 poz. 458.

14. Centers for Disease Control and Prevention National Diabetes Statistics Report, 2020 https://www.cdc.gov/diabetes/pdfs/data/statistics/national-diabetes-statistics-report.pdf dostęp 30.04.2020.

15. Magliano DJ, Islam RM, Barr ELM, et al. Trends in incidence of total or type 2 diabetes: systematic review. BMJ. 2019; 366: 15003, doi: 10.1136/bmj.15003, indexed in Pubmed: 31511236.

16. Xu G, Liu B, Sun Y, et al. Prevalence of diagnosed type 1 and type 2 diabetes among US adults in 2016 and 2017: population based study. BMJ. 2018; 362: k1497, doi: 10.1136/bmj.k1497, indexed in Pubmed: 30181166.

17. https://www.idf.org/aboutdiabetes/type-2-diabetes.html dostęp 03.05.2020.

18. Patterson CC, Harjutsalo V, Rosenbauer J, et al. Trends and cyclical variation in the incidence of childhood type 1 diabetes in 26 European centres in the 25 year period 1989-2013: a multicentre prospective registration study. Diabetologia. 2019; 62(3): 408-417, doi: 10.1007/s00125-018-4763-3, indexed in Pubmed: 30483858.

19. Thomas NJ, Jones SE, Weedon MN, et al. Frequency and phenotype of type 1 diabetes in the first six decades of life: a crosssectional, genetically stratified survival analysis from UK Biobank. Lancet Diabetes Endocrinol. 2018; 6(2): 122-129, doi: 10.1016/ S2213-8587(17)30362-5, indexed in Pubmed: 29199115.

20. Rogers MAM, Kim C, Banerjee $T$, et al. Fluctuations in the incidence of type 1 diabetes in the United States from 2001 to 2015: a longitudinal study. BMC Med. 2017; 15(1): 199, doi: 10.1186/ s12916-017-0958-6, indexed in Pubmed: 29115947.

21. Bruno G, Runzo C, Cavallo-Perin P, et al. Piedmont Study Group for Diabetes Epidemiology. Incidence of type 1 and type 2 diabetes in adults aged 30-49 years: the population-based registry in the province of Turin, Italy. Diabetes Care. 2005; 28(11): 2613-2619, doi: 10.2337/diacare.28.11.2613, indexed in Pubmed: 16249528.

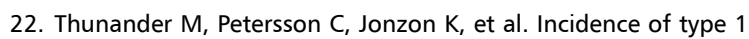
and type 2 diabetes in adults and children in Kronoberg, Sweden. Diabetes Res Clin Pract. 2008; 82(2): 247-255, doi: 10.1016/j. diabres.2008.07.022, indexed in Pubmed: 18804305. 